\title{
Integrasi Teori Van Hiele pada LKPD Materi Bangun Ruang Sisi Datar untuk Mendukung Peningkatan Kemampuan Visual Spasial Siswa SMP
}

\author{
Nia Nilamsari ${ }^{1)}$, Sri Rejeki ${ }^{2)}$ \\ Universitas Muhammadiyah Surakarta ${ }^{1), 2)}$ \\ Email korespondensi : $\underline{\text { sri.rejeki@ums.ac.id }}{ }^{2}$
}

\begin{abstract}
Abstrak. Penelitian dan pengembangan ini bertujuan untuk mendeskripsikan pengembangan Lembar Kerja Peserta Didik (LKPD) berbasis teori van Hiele pada Materi Bangun Ruang Sisi Datar untuk Mendukung Peningkatan Kemampuan Visual Spasial Siswa SMP dan menganalisis kevalidan serta kelayakan Lembar Kerja Peserta Didik (LKPD) berbasis teori van Hiele pada Materi Bangun Ruang Sisi Datar untuk Mendukung Peningkatan Kemampuan Visual Spasial Siswa SMP. Metode penelitian yang digunakan adalah metode ADDIE (Analysis, Design, Development, Implementation, Evaluation). Tahap pengembangan dalam penelitian ini adalah studi pendahuluan, perencanaan, dan pengembangan lembar kerja, validasi lembar kerja, dan uji kelayakan lembar kerja. Subjek penelitian ini adalah peserta didik kelas IX SMP Negeri 2 Plupuh di tahun ajaran 2020/2021. Data yang diperoleh dari penelitian ini adalah observasi dan penilaian angket. Validasi lembar kerja oleh dua ahli materi dan satu ahli media, hasil uji kevalidan lembar kerja menunjukkan bahwa lembar kerja dinyatakan valid dengan skor rata-rata 4 . Hasil uji kelayakan berdasarkan angket dari peserta didik menunjukkan skor ratarata 3.6 dengan kategori sangat layak.
\end{abstract}

Kata kunci: lembar kerja peserta didik (lkpd), teori van hiele, visual spasial.

\begin{abstract}
Abstarct. This research and development aims to describes the development of student worksheets based on van Hiele's theory on the Flat Side Building Material to Support the Improvement of Junior High School Students' Spatial Visual Ability and analyzes the validity and feasibility of van Hiele's theory-based Student Worksheets on Flat Side Building Material for Supporting the Improvement of Junior High School Students' Spatial Visual Ability. The research method used is the ADDIE method (Analysis, Design, Development, Implementation, Evaluation). The development phase in this research is a preliminary study, planning, and development of worksheets, validation of worksheets, and the feasibility test of worksheets. The subjects of this study were students of grade IX SMP Negeri 2 Plupuh in 2020/2021 school year. Data obtained from this study were observation and questionnaire assessment. Validation of worksheets by two material experts and one media expert, the results of the validity of the worksheets showed that the worksheets were declared valid with an average score of 4 . The results of the feasibility test based on a questionnaire from students showed an average score of 3.6 with a very decent category.
\end{abstract}

Keywords: student worksheets, van hiele theory, visual spatial. 


\section{PENDAHULUAN}

Dalam kehidupan sehari-hari ilmu matematika sangat penting digunakan. Ilmu matematika sebagai instrumen untuk memecahkan permasalahan sehari-hari (Ayllón et ala, 2016). Matematika dapat meningkatkan kecerdasan peserta didik dalam menghadapi permasalahan sehari-hari. Timmins (1996) menyatakan bahwa Gardner telah mengidentifikasi bahwa terdapat delapan jenis kecerdasan seseorang, yaitu 1) linguistik/kecerdasan verbal, 2) logika/matematika, 3) verbal/spasial, 4) musik, 5) tubuh/kinestetik, 6) kemampuan interpersonal dan 7) kemampuan intrapersonal dan 8) naturalistik. Oleh karena itu, matematika berkaitan erat dengan kemampuan verbal/spasial.

Dasar teori untuk mengeksplorasi masalah kemampuan penalaran spasial berakar pada konsep bahwa kompetensi sama pentingnya dengan kemampuan verbal dan matematika (Pierre, 1988). Kemampuan spasial mempengaruhi banyak bidang dan disiplin ilmu dan merupakan prediktor untuk sukses dibanyak bidang kehidupan (Mohler, 2008). Dengan demikian, tenaga pendidik harus merefleksikan keyakinan dan praktik tentang kemampuan kecerdasan visual spasial di semua tahap pendidikan dan kecerdasan spasial harus disediakan pengaturan pendidikan awal (Diezmann et al, 2000). Oleh karena itu, kemampuan visual spasial perlu dikembangkan dan ditingkatkan dalam pembelajaran matematika.

Salah satu usaha untuk memaksimalkan kemampuan visual spasial siswa adalah dengan menggunakan teori van hiele. Level berpikir teori van hiele dapat memudahkan peserta didik dalam menyelesaikan masalah dari masalah yang mudah ke yang sulit. Tahapan teori ini dapat melatih siswa dalam menyelesaikan masalah dengan tingkat kematangan berpikirnya. Model pembelajaran van hiele dapat memberikan dampak yang positif untuk meningkatkan kemampuan spasial siswa dibandingkan dengan pembelajaran konvensional (Pujawan et al, 2020). Modul materi lingkaran berbasis teori van hiele dinyatakan valid untuk digunakan sebagai media pembelajaran berdasarkan hasil validasi ahli, uji coba lapangan di kelas, dan uji keterbacaan modul (Sari et al, 2019).

Prastowo (2015) mengemukakan bahwa instrumen pengajaran dalam bentuk media cetak yang berupa lembaran-lembaran yang di dalamnya terdapat arahan yang harus dilaksanakan oleh peserta didik, ringkasan, materi dan tugas yang 
disesuaikan dengan kompetensi dasar harus dicapai adalah LKPD (Lembar Kerja Peserta Didik). LKPD yang dibuat memiliki komponen yang dapat menuntun peserta didik memahami isi materi dan mencapai tujuan pembelajaran. Dengan demikian, peserta didik dituntun agar tujuan pembelajaran tercapai sesuai apa yang diharapkan.

Fakta mengenai LKPD yang digunakan oleh pendidik atau guru saat ini menunjukkan bahwa masih adanya kekurangan didalamnya. Hasil wawancara terhadap guru mata pelajaran matematika di SMP Negeri 2 Plupuh diketahui LKPD yang digunakan saat ini masih konvensional yaitu menjelaskan materi lalu memberikan contoh soal pelajaran. LKPD yang saat ini digunakan belum bisa meningkatkan kemampuan visual spasial. Siswa cenderung kurang maksimal pada kemampuan visual spasial.

Berdasarkan permasalahan di atas, peneliti mengkaji bahwa penggunaan LKPD sangat penting. LKPD berfungsi sebagai perangkat pembelajaran yang dapat memudahkan proses pembelajaran (Prastowo, 2015). Hasil penelitian terdahulu menunjukkan bahwa pengembangan LKPD telah dilakukan untuk mendukung proses pembelajaran pada materi-materi tertentu, misalnya garis dan sudut (Prastika, 2018), persegi dan persegi panjang (Choirudin, Anwar, Azizah, Wawan, \& Wahyudi, 2021), dan bangun ruang (Waluto, Sa'dijah, \& Subanji, 2016)

Oleh karena itu, dalam konteks materi bangun ruang sisi datar, pengembangan LKPD yang berbasis teori van hiele merupakan salah satu upaya untuk meningkatkan kemampuan kecerdasan visual spasial peserta didik. Dengan mengimplementasikan teori van hiele dalam pembuatan LKPD, peneliti mengharapkan peserta didik dapat berperan aktif dalam proses pembelajaran dan mengasah kemampuan visual spasial yang dimiliki.

Permasalahan mata pelajaran yang berkaitan dengan kemampuan kecerdasan visual spasial adalah mata pelajaran geometri. Materi geometri terdapat beberapa materi didalamnya salah satu diantaranya adalah bangun ruang sisi datar. Dengan demikian, diperlukan pengembangan LKPD pada materi bangun ruang sisi datar agar peserta didik dapat meningkatkan kemampuan kecerdasan visual spasial. Wenas et al (2017) menyatakan bahwa kecerdasan visual spasial dengan hasil 
belajar matematika peserta didik pada materi geometri terdapat hubungan yang positif sebesar $66 \%$ secara signifikan.

Berdasarkan uraian di atas, penelitian ini bertujuan untuk mengembangkan LKPD berbasis teori van Hiele pada materi bangun ruang sisi datar untuk mendukung peningkatan kemampuan visual spasial siswa SMP.

\section{METODE PENELITIAN}

Metode penelitian yang digunakan adalah research and development dengan dengan menggunakan model ADDIE. Sutama (2019) menyatakan bahwa Research and Development (R\&D) adalah sebuah strategi metode penelitian yang ampuh untuk memperbaiki praktik dan suatu proses untuk mengembangkan suatu produk baru atau menyempurnakan produk yang telah ada yang dapat dipertanggungjawabkan. model ADDIE terdiri dari 5 komponen, yaitu: analisis, perancangan, pengembangan, implementasi, dan evaluasi. Model ADDIE adalah salah pendekatan yang yang membantu guru untuk membuat desain pengajaran yang efektif dengan menerapkan proses model ADDIE pada produk instruksional apapun (Aldoobie, 2015). Usiskin (1982) menyatakan bahwa ada lima langkah pembelajaran yang digunakan dalam teori van hiele, yaitu 1) Inkuiri, 2) Orientasi Terbimbing, 3) Penjelasan, 4) Orientasi Bebas, dan 5) Integrasi.

\section{Tahap Analisis (Analysis)}

Tahap analisis yang dilakukan oleh peneliti berupa menganlisis kompetensi, kriteria siswa dan analisis materi. Analisis kompetensi mengenai kompetensi inti dan kompetensi dasar. Analisis karakteristik siswa melakukan wawancara terhadap guru matematika. analisi materi bangun ruang sisi datar yang mengacu pada kompetensi dasar untuk SMP/MTs kelas VII berdasarkan Permendikbud No. 37 tahun 2018.

2. Tahap Perancangan (Design)

Perancangan LKPD berbasis teori van hiele pada materi bangun ruang sisi datar untuk mendukung kemampuan visual spasial siswa SMP meliputi: 1) persiapan pembuatan produk, 2) Penyusunan kerangka dasar LKPD, 3) Penyusunan instrumen penilaian.

3. Tahap Pengembangan (Development) 
Pada tahap pengembangan dilakukan validasi terhadap desain yang sudah dirancang. Dalam langkah ini, kegiatan yang dikakukan adalah menilai kevalidan rencangan LKPD yang akan digunakan dalam proses pembelajaran. Validasi dilakukan dengan cara meminta beberapa orang pakar atau tim ahli yang sudah berpengalaman untuk menilai desain yang telah dirancang sehingga dapat diketahui kekuatan dan kelemahan dari instrumen tersebut. Revisi sesuai dengan saran dan masukkan dari para ahli sampai produk dikatakan valid untuk diujicobakan.

4. Tahap Implementasi (Implementation)

Uji coba LKPD untuk melihat keefektifan LKPD. Dalam penelitian ini produk yang berupa LKPD matematika yang telah divalidasi diujikan 9 siswa kelas IX SMP Negeri 2 Plupuh dengan memberikan LKPD tersebut kemudian siswa diminta mengisi angket yang telah disediakan. Angket yang diberikan berupa angket kepada siswa diminta untuk berkomentar secara bebas mengenai LKPD yang telah diujicobakan dengan tujuan untuk mempermudah peneliti dalam merevisi LKPD.

\section{Tahap Evaluasi (Evaluation)}

Setelah hasil uji coba dan saran dari beberapa pihak dilakukan, maka tahap selanjutnya adalah evaluasi produk. Evaluasi produk dilakukan dengan cara mengamati hasil validitas dari pengguna LKPD, hasil tersebut perlu dilakukan perbaikan apabila masih ada hal-hal yang kurang agar LKPD lebih efektif saat digunakan selanjutnya.

Teknik pengumpulan data yang digunakan penelitian adalah wawancara dan angket. Wawancara dilakukan pada tahap analisis untuk mendapatkan informasi mengenai kompetensi, karakter siswa dan materi. Angket digunakan pada tahap pengembangan untuk mengetahui kevalidan LKPD berbasis teori van hiele pada materi bangun ruang sisi datar untuk mendukung kemampuan visual spasial siswa SMP yang sedang dikembangkan. angket juga digunakan pada tahap implementasi untuk mengetahui kelayakan LKPD.

Data hasil angket menggunakan kualitatif dan kuantitatif untuk menentukan nilai rata-rata skor kemudian dikonversi ke data kualitatif. Analisis data pada angket 
menurut Sugiyono (2013:146) menggunakan skala Likert. Berikut langkahlangkahnya:

1. Menghitung skor rata-rata dari angket siswa menurut Arikunto (2010) $x=$ $\frac{1}{\text { banyak responden }} \times \frac{\sum x}{n}$

Keterangan:

$x=$ skor rata-rata

$\sum x=$ jumlah skor yag diperoleh

$\mathrm{n} \quad$ = banyak pertanyaan

Penskoran angket siswa menggunakan skala 1-4 sebagaimana ditunjukkan pada Tabel 1 (Arikunto, 2010).

\begin{tabular}{cc}
\hline Data Kualitatif & Skor \\
\hline Setuju & 4 \\
Cukup setuju & 3 \\
Kurang setuju & 2 \\
Tidak setuju & 1 \\
\hline
\end{tabular}

Tabel 1. Pedoman Skor Angket Siswa

2. Skor rata-rata yang diperoleh dikonversikan dalam data kualitatif skala lima menurut Widoyoko (2009) sebagaimana ditunjukkan oleh Tabel 2.

\begin{tabular}{ccc}
\hline Nilai & Rentang skor & Kategori \\
\hline $\mathrm{A}$ & $\mathrm{X}>\mathrm{Mi}+1,8 \mathrm{Sbi}$ & Sangat layak \\
$\mathrm{B}$ & $\mathrm{Mi}+0,6 \mathrm{Sbi}<\mathrm{X} \leq \mathrm{Mi}+1,8 \mathrm{Sbi}$ & Layak \\
$\mathrm{C}$ & $\mathrm{Mi}-0,6 \mathrm{Sbi}<\mathrm{X} \leq \mathrm{Mi}+0,6 \mathrm{Sbi}$ & Cukup layak \\
$\mathrm{D}$ & $\mathrm{Mi}-1,8 \mathrm{Sbi}<\mathrm{X} \leq \mathrm{Mi}-0,6 \mathrm{Sbi}$ & Kurang layak \\
$\mathrm{E}$ & $\mathrm{X} \leq 1,6$ & Tidak layak \\
\hline
\end{tabular}

Tabel 2. Konversi Data Kuantitatif ke Data Kualitatif

Keterangan:

$\mathrm{X}=$ skor rata-rata

$\mathrm{Mi} \quad=$ rata-rata ideal

$=\frac{1}{2}($ skor maksimal ideal + skor minimal ideal $)$

Sbi $\quad=$ simpangan baku

$=\frac{1}{6}($ skor maksimal ideal - skor minimal ideal $)$

Skor Maksimal Ideal = skor tertinggi

Skor Minimal Ideal = skor terendah

Dalam angket tersebut skor tertinggi yang dapat diberikan validator adalah 4 dan skor terendah adalah 1, sehingga didapatkan kriteria valid sebagaimana dideskripsikan pada Tabel 3. 


\begin{tabular}{ccc}
\hline Nilai & Rentang skor & Kategori \\
\hline A & $X>3,4$ & Sangat layak \\
B & $2,8<X \leq 3,4$ & Layak \\
C & $2,2<X \leq 2,8$ & Cukup layak \\
D & $1,6<X \leq 2,2$ & Kurang layak \\
E & $X \leq 1,6$ & Tidak layak \\
\hline
\end{tabular}

Tabel 3. Kriteria Kelayakan LKPD

\section{HASIL DAN PEMBAHASAN}

Integrasi LKPD berbasis teori van hiele pada materi bangun ruang sisi datar untuk mendukung kemampuan visual spasial siswa SMP dilakukan dengan cara research and development atau $\mathrm{R} \& \mathrm{D}$. Tahap integrasi LKPD berbasis teori van hiele pada materi bangun ruang sisi datar untuk mendukung peningkatan kemampuan visual spasial siswa SMP menggunakan tahap ADDIE. Tahapan metode ADDIE meliputi analisis, desain, pengembangan, implementasi, dan tahap evaluasi, namun peneliti tidak melakukan sampai tahap evaluasi melainkan hanya sampai tahap implementasi. Hal ini sejalan dengan penelitian Mahnun et al (2012) yang menyatakan media adalah bagian dari fungsi media dalam pembelajaran, komponen pembelajaran dan manfaat yang dirasakan oleh peserta didik dan tenaga pendidik, sedangkan memilih media pembelajaran sangat penting untuk mendukung kualitas belajar peserta didik. Dwiningsih (2021) menyatakan bahwa LKPD dapat digunakan sebagai bahan ajar untuk melatih visual spasial siswa.

Analisis atau analysis kompetensi ini mengacu Permendikbud nomor 37 tahun 2018 tentang kompetensi inti dan kompetensi dasar matematika sebagai dasar capaian peserta didik SMP/MTs kelas VIII. Analisis Kebutuhan peserta didik dilakukan dengan observasi dan wawancara kepada tiga guru mata pelajaran matematika SMP Negeri 2 Plupuh oleh peneliti. Analisis karakteristik peserta didik dilakukan dengan observasi dan wawancara kepada tiga guru mata pelajaran matematika SMP Negeri 2 Plupuh. Hasil wawancara didapatkan hasil berikut:

1) Peserta didik kurang aktif pada sat ada diskusi yang diadakan oleh guru.

2) Tidak jarang peserta didik bermain saat pelajaran berlangsung.

3) Berbagai respon peserta didik terhadap pembelajaran matematika.

4) Metode pembelajaran yang kadang tidak sesuai dengan kondisi di kelas. 
5) Tidak semua kelas VIII pernah menggunakan LKPD sebagai bahan ajar awal dalam pembelajaran.

6) Peserta didik masih merasa kebingungan saat menagerjakan soal karena belum paham konsep awal.

Analisis Materi yang akan dikembangkan dengan Lembar Kerja Peserta Didik (LKPD) berbasis teori van hiele oleh peneliti yaitu bangun ruang sisi datar pada kompetensi dasar 3.9 dan 4.9 .

Perancangan atau design dimulai dari persiapan pembuatan produk, Penyusunan Kerangka Dasar LKPD, Penyusunan instrumen penilaian. Persiapan pembuatan LKPD peneliti melakukan studi literatur untuk mendapatkan informasi dalam penyusunan Lembar Kerja Peserta Didik (LKPD). Penyusunan kerangka dasar LKPD dimulai dari sampul, identitas peserta didik, identitas pembuat LKPD, kata pengantar, petunjuk umum LKPD, kompetensi dasar dan indikator pencapaian kompetensi, masalah atau isi LKPD, dan daftar pustaka. Penyusunan instrumen penelitian yang digunakan dalam LKPD berbasis teori van hiele materi bangun ruang sisi datar untuk mendukung kemampuan visual spasial diantaranya pembahasan kemungkinan jawaban yang tepat untuk setiap petunjuk, penskoran tiap butir kemungkinan jawaban, penskoran utuh tiap petunjuk, dan penjumlahan total skor yang diperoleh.

Pengembangan atau Development LKPD dimulai dari proses pembuatan LKPD dan validasi. Proses pembuatan LKPD ada beberapa langkah, mulai pembuatan sampul LKPD, identitas peserta didik dan penyusun, kata pengantar, petunjuk umum penggunaan, perumusan kompetensi dasar dan indikator pencapaian kompetensi, perumusan tujuan pembelajaran, pembuatan masalah atau isi LKPD. LKPD berisi masalah sesuai indikator teori van hiele dan kemampuan visual spasial. Masalah atau isi LKPD berbasis teori van hiele pada materi bangun ruang sisi datar untuk mendukung kemampuan visual spasial siswa SMP diuraikan sebagai berikut:

1. Inkuiri. Pada tahap ini, interaksi dua arah guru dan siswa sangat penting dalam memahami sesuatu bentuk geometris seperti melakukan observasi, mengajukan pertanyaan dan memahami kosakata untuk itu bentuk geometris tertentu. Kegiatan inkuiri LKPD pertemuan 1 disajikan pada Gambar 1. 


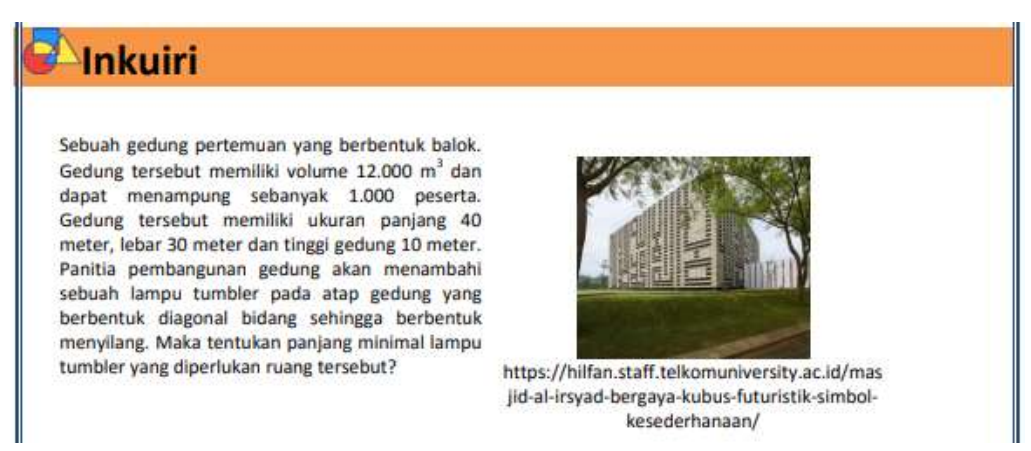

\section{Gambar 1. Inkuiri LKPD Pertemuan 1}

2. Orientasi terbimbing. Siswa mendalami topik geometri yang disusun oleh guru. Aktivitas terlibat harus memungkinkan siswa untuk mengidentifikasi bentuk geometris yang akan dipelajari. Oleh karena itu, untuk pelajaruntuk menguasai level, mereka harus diberi tugas yang lebih sederhana. Kegiatan orientasi terbimbing LKPD pertemuan 1 disajikan pada Gambar 2.

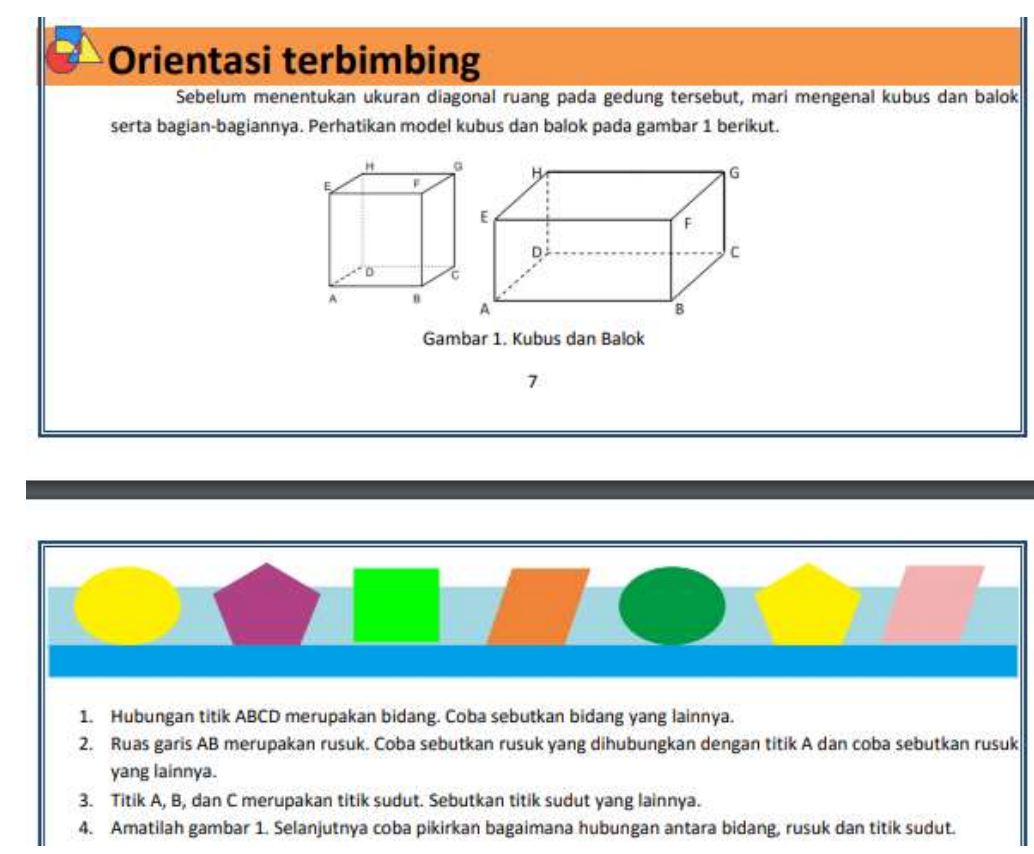

Gambar 2. Orientasi Terbimbing LKPD Pertemuan 1

3. Penjelasan. Berdasarkan pengalaman sebelumnya, peserta didik mengungkapkan pendapatnya dan berdiskusi bentuk geometris yang telah diamati. Pada tahap ini, guru hanya berperan sebagai fasilitator. Kegiatan penjelasan LKPD pertemuan 1 disajikan pada Gambar 3. 




Gambar 3. Penjelasan LKPD Pertemuan 1

4. Orientasi Bebas. Peserta didik mampu memecahkan masalah yang lebih rumit seperti soal terbuka masalah. Mereka memperoleh pengalaman dengan menemukan solusi mereka sendiri atau dengan menyelesaikan tugas. Sebagian besar Hubungan antar objek diperjelas melalui interaksi antar peserta didik saat melakukan investigasi. Kegiatan orientasi bebas LKPD pertemuan 1 disajikan pada Gambar 4.

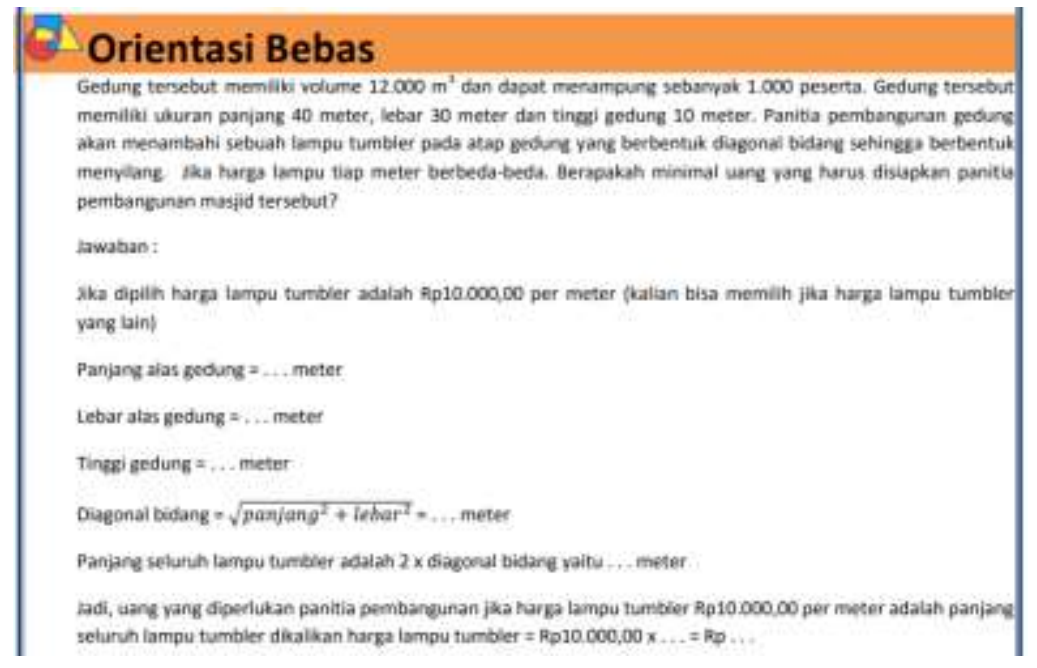

\section{Gambar 4. Orientasi Bebas LKPD Pertemuan 1}

5. Integrasi. Peserta didik mensurvei dan meringkas apa yang telah mereka pelajari dengan membuat hubungan di antara mereka bentuk geometris. Untuk meningkatkan semangat belajar peserta didik dan memfasilitasi proses pembelajaran yang menggunakan teori van hiele tersebut tercapai sesuai apa yang diinginkan maka diperlukan suatu alat atau instrumen lembar kerja peserta didik (LKPD). Kegiatan integrasi LKPD pertemuan 1 disajikan pada Gambar 5. 


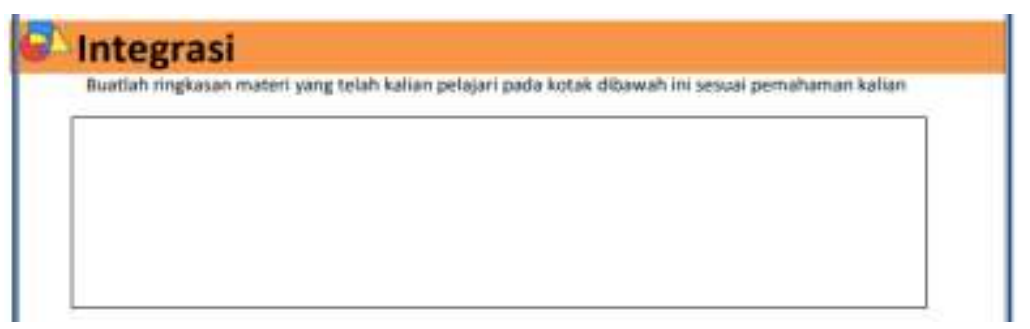

Gambar 5. Integrasi LKPD Pertemuan 1

Pada proses validasi untuk mengetahui kevalidan LKPD yang telah dirancang oleh peneliti berisikan angket dan catatan revisi dari validator. Peneliti mengambil dua validator, yakni dari seorang dosen pendidikan matematika dan seorang guru matematika. Masing-masing validator mendapatkan Lembar Kerja Peserta Didik (LKPD), lembar validasi yang terdiri dari kisi-kisi angket dan angket validasi. Hasil validasi tersebut diperoleh hasil sebagaimana dideskripsikan pada Tabel 4.

\begin{tabular}{|c|c|c|c|c|c|}
\hline No & $\begin{array}{c}\text { Ketercapaian } \\
\text { Indikator }\end{array}$ & Aspek & $\begin{array}{c}\text { Jumlah } \\
\text { Butir }\end{array}$ & Rerata & Keterangan \\
\hline \multirow[t]{3}{*}{1} & $\begin{array}{l}\text { Lembar Kerja } \\
\text { Peserta Didik }\end{array}$ & Isi yang disajikan & 9 & 4 & Valid \\
\hline & & Bahasa & 7 & 4,3 & Sangat valid \\
\hline & & Kegrafikan & 3 & 4 & Valid \\
\hline 2 & Teori van Hiele & $\begin{array}{l}\text { Kegiatan berbasis } \\
\text { teori van hiele }\end{array}$ & 6 & 3,8 & Valid \\
\hline 4 & $\begin{array}{l}\text { Kemampuan } \\
\text { Visual Spasial }\end{array}$ & $\begin{array}{l}\text { Kemampuan visual } \\
\text { spasial }\end{array}$ & 5 & 4,2 & Valid \\
\hline \multicolumn{3}{|c|}{ Kesimpulan } & 30 & 4 & Valid \\
\hline
\end{tabular}

Analisis pada angket telah dilakukan oleh peneliti, didapat hasil rata-rata skor 4 dengan kategori Valid. Berdasarkan hasil analisis angket validasi di atas disimpulkan bahwa Lembar Kerja Peserta Didik (LKPD) berbasis teori van hiele untuk mendukung peningkatan kemampuan visual spasial siswa SMP sesuai dengan indikator.

Sebelum mendapatkan kevalidan dari ahli, LKPD terdapat beberapa revisi dari validator. Hasil revisi dari validator diperoleh saran lisan dan saran tertulis dalam lembar validasi. Hasil revisi dari kedua validator. Berikut ini adalah komentar dan saran dari validator:

1. Secara umum, LKPD telah sesuai dengan langkah van Hiele.

2. Tinjau ulang kesesuaian setiap kegiatan di LKPD dengan indikator tahap van Hiele yang sudah ditetapkan dalam penelitian ini. 
3. Pada aktivitas praktek, tinjau detail petunjuknya agar peserta didik dapat lebih mudah mengikuti instruksinya.

4. Bisa dipertimbangkan peserta didik diminta membawa kardus berkas atau barang lain saja, dibandingkan membuat bangun ruang dalam mempelajari jaring-jaring atau proses pembuatan bangunnya jangan terlalu banyak. Dalam 1 pertemuan, tercatat peserta didik harus membuat 4 kubus dan 4 balok yang cukup menguras waktu.

5. Sebaiknya dikaji maksud pertanyaan soal terbuka pada orientasi bebas. LKPD belum memuat pertanyaan terbuka.

6. Penulisan LKPD Pertemuan 1 yang kurang menarik.

Hasil screenshot LKPD sebelum dan sesudah revisi sebagai berikut:

\section{$\underline{\text { Penulisan LKPD Pertemuan }}$}

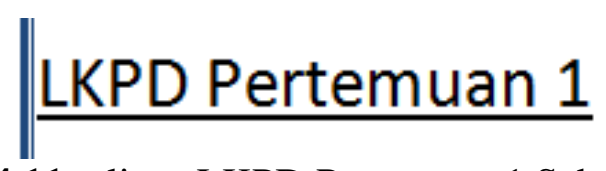

Gambar 4.11 tulisan LKPD Pertemuan 1 Sebelum revisi

\section{UNPDD PERTEMOAN 1}

Gambar 4.12 tulisan LKPD Pertemuan 1 Sesudah direvisi Tahap penjelasan pada teori van hiele yang belum sesuai teori

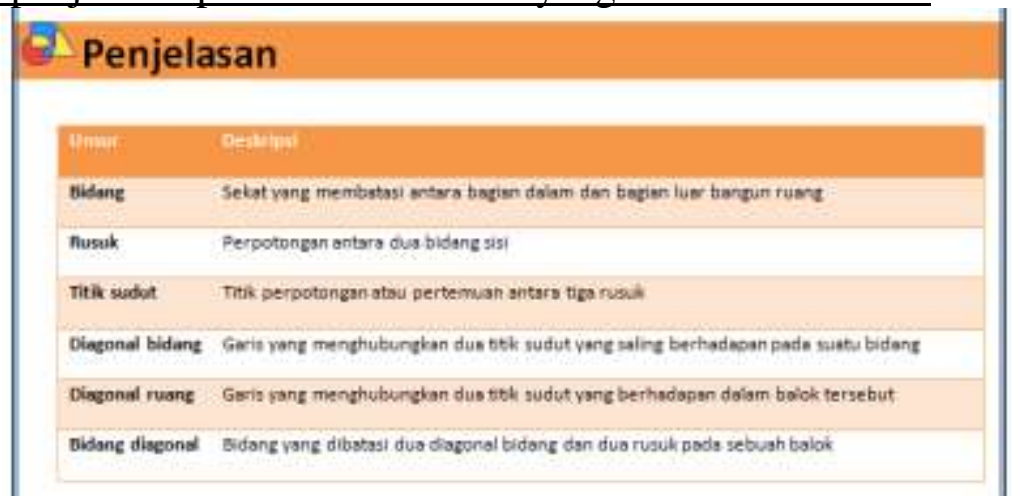

Gambar 4.13 Tahap Penjelasan sebelum direvisi

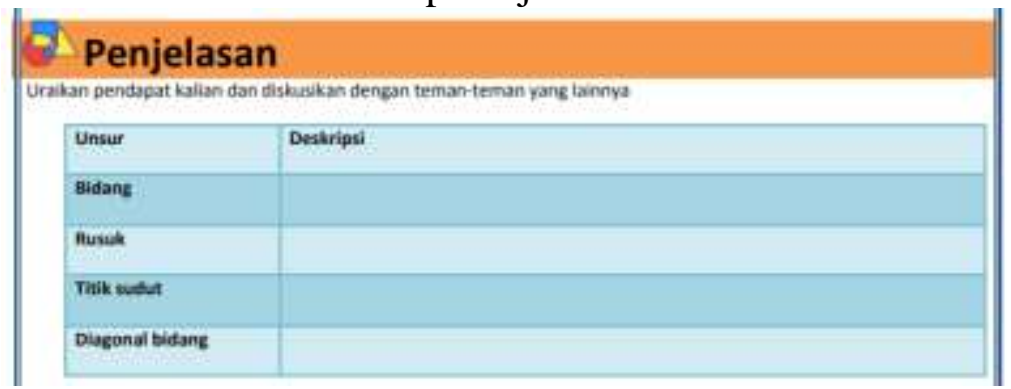

Gambar 4.14 Tahap Penjelasan Sesudah revisi 
$\underline{\text { Tahap orientasi bebas }}$

Orientasi Bebas
Gedung tersebut memiliki volume $12.000 \mathrm{~m}^{3}$ dan dapat menampung sebanyak 1.000 peserta. Gedung tersebut memillii
ukuran panjang 40 meter, lebar 30 meter dan tinggi gedung 10 meter. Panitia pembangunan gedung akan menambahi
sebuah lampu hiasan di dalam ruangan dengan bentuk seperti diagonal ruang. Berapakah ukuran panjang diagonal
ruang tersebut?
Jawaban :
Panjang alas gedung $=\ldots$ meter
Lebar alas gedung $=\ldots$ meter
Tinggi gedung $=\ldots$. meter
Diagonal bidang alas $=\ldots$ meter (menggunakan rumus theorema phytagoras antara panjang dan lebar alas)
Diagonal ruang $=\ldots . .$. meter (gunakan rumus theorema phytagoras antara diagonal bidang alas dan tinggi gedung)

Gambar 4.15 Tahap Orientasi Bebas Sebelum Revisi

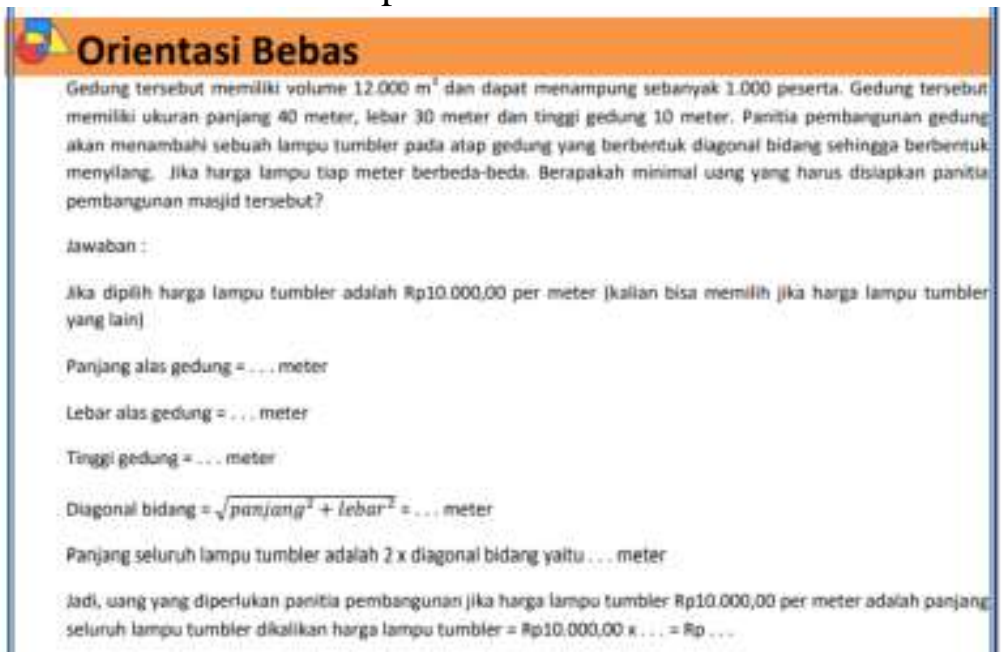

Gambar 4.15 Tahap Orientasi Bebas sesudah revisi

$\underline{\text { Tahap integrasi }}$

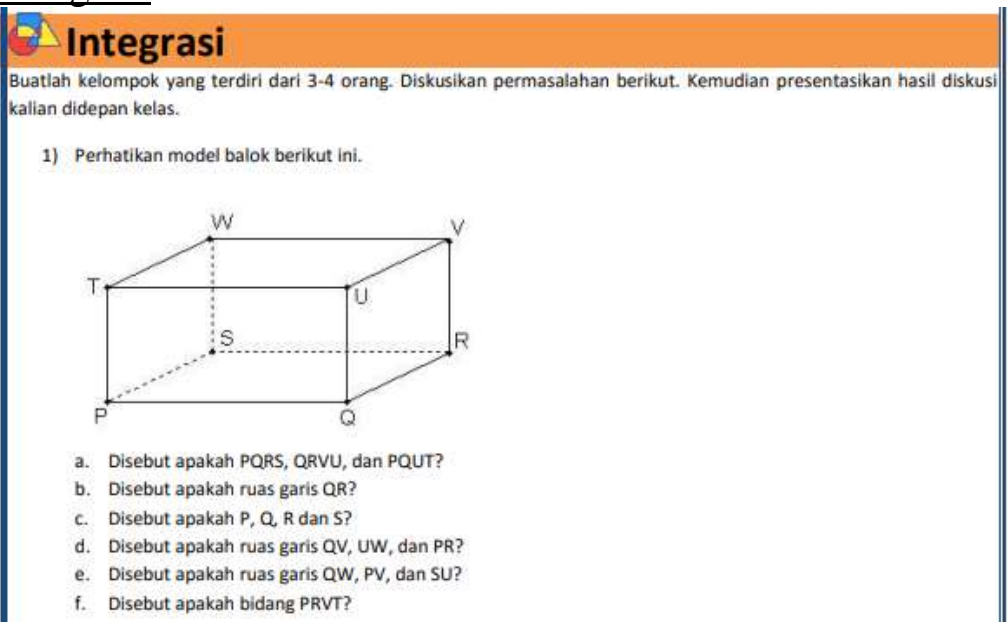

Gambar 4.16 Tahap Integrasi sebelum revisi

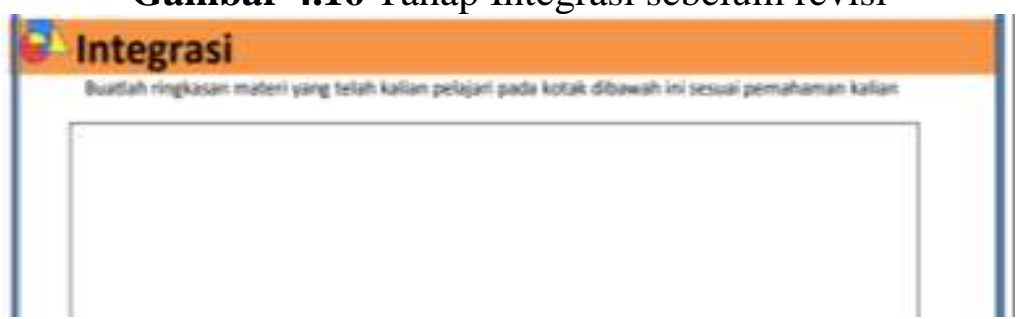

Gambar 4.17 Tahap Integrasi sesudah revisi 
Setelah LKPD dinyatakan valid, maka tahap selanjutnya yaitu uji coba produk atau implementasi (Implementation ). Implementasi diuji cobakan kepada peserta didik kelas IX. Uji coba dilakukan dengan mengambil sampel sampel kelompok kecil berjumlah 9 peserta didik. Pengambilan sampel sesuai dengan saran guru matematika kelas tersebut, yang kemudian peserta didik diperintahkan untuk mengisi angket kelayakan LKPD dengan diberikan LKPD berbasis teori van hiele yang telah disusun oleh peneliti. Tabel 5 menunjukkan hasil pengisian angket oleh 9 peserta didik:

\begin{tabular}{ccccc}
\hline No & Komponen & Jumlah Butir & Rerata & Keterangan \\
\hline 1 & Isi & 9 & 3,5 & Sangat layak \\
2 & Bahasa & 2 & 3,5 & Sangat layak \\
3 & Penyajian & 5 & 3,7 & Sangat layak \\
4 & Kegrafikan & 4 & 3,6 & Sangat layak \\
\hline & Kesimpulan & 20 & 3,6 & Sangat layak \\
\hline
\end{tabular}

Tabel 5. Hasil Angket Peserta Didik

Setelah dilakukan analisis kelayakan terhadap angket yang diisi peserta didik, diperoleh skor rata-rata 3,6 dengan kategori sangat layak. Sehingga, Lembar Kerja Peserta Didik (LKPD) berbasis teori van hiele materi bangun ruang sisi datar dapat dijadikan media untuk proses pembelajaran.

Tahap pengembangan LKPD berbasis teori van hiele pada materi bangun ruang sisi datar untuk mendukung peningkatan kemampuan visual spasial siswa SMP menggunakan tahap ADDIE. Tahapan metode ADDIE meliputi analisis, desain, pengembangan, implementasi, dan tahap evaluasi, namun peneliti tidak melakukan sampai tahap evaluasi melainkan hanya sampai tahap implementasi. Hal ini sejalan dengan penelitian Mahnun et al (2012) yang menyatakan media adalah bagian dari fungsi media dalam pembelajaran, komponen pembelajaran dan manfaat yang dirasakan oleh peserta didik dan tenaga pendidik, sedangkan memilih media pembelajaran sangat penting untuk mendukung kualitas belajar peserta didik. Dwiningsih (2021) menyatakan bahwa LKPD dapat digunakan sebagai bahan ajar untuk melatih visual spasial siswa.

Hasil penelitian dan pengembangan ini adalah media pembelajaran berbasis teori van hiele materi bangun ruang sisi datar untuk mendukung peningkatan kemampuan visual spasial siswa SMP. LKPD ini dapat digunakan alat bantu guru saat kegiatan pembelajaran mata pelajaran bangun ruang sisi datar untuk siswa kelas VIII semester genap di tingkat SMP. Media ini telah divalidasi oleh ahli 
materi dan ahli teori van hiele serta memperoleh kategori valid dan layak berdasarkan hasil validasi oleh ahli materi, ahli media, ahli teori van hiele dan pengguna media. Setelah melakukan revisi, berdasarkan hasil validasi yang dilakukan dengan beberapa ahli disusunlah LKPD berbasis teori van hiele materi bangun ruang sisi datar untuk mendukung peningkatan kemampuan visual spasial siswa SMP.

Penilaian kevalidan LKPD didasarkan pada dua indikator yaitu indikator ketercapaian lembar kerja peserta didik dan indikator kemampuan visual spasial. prastowo (2015) menyatakan indikator lembar kerja peserta didik ada 6 yaitu petunjuk belajar, kompetensi yang akan dicapai, infromasi pendukung, latihanlatihan, lembar kegiatan, dan evaluasi. Rizkiana et al (2015) Indikator kemampuan visual spasial ada 5 yaitu 1) Menyatakan unsur-unsur suatu bangun ruang, 2) Mengidentifikasi dan mengklarifikasi gambar bangun ruang, 3) Membayangkan bentuk atau posisi suatu bangun ruang yang dipandang dari sudut pandang tertentu, 4) Mengontruksi dan merepresentasikan model-model bangun ruang, 5) Menginvestigasi suatu gambar ruang. Hasil penilaian kevalidan LKPD memperoleh skor 4 dengan kategori “valid”. Sejalan dengan penelitian Hermawan et al (2019) menyatakan hasil penelitian LKPD berbasis komik strip dengan hasil analisis data penelitian menunjukkan rata-rata skor persentase validitas sebesar 81,7905\% yang telah divalidasi oleh ahli materi dan ahli media.

Penilaian kelayakan didasarkan pada aspek penggunaan lembar kerja peserta didik. peneliti menghitung hasil angket menggunakan perhitungan skala Likert. Hasil perhitungan dapat dilihat pada Table 4.6 yang menghasilkan skor rata-rata 3,6 dengan kategori sangat layak. Bahan ajar merupakan segala bahan (baik informasi, alat, maupun teks) yang menampilkan kompetensi yang harus dikuasai peserta didik yang tersusun secara sistematis dan utuh sehingga dapat digunakan dalam proses pembelajaran dengan tujuan perencanaan dan penelaahan implementasi pembelajaran (Prastowo, 2015) sehingga LKPD berbasis teori van hiele materi bangun ruang sisi datar untuk mendukung kemampuan visual spasial siswa SMP layak digunakan. 


\section{KESIMPULAN}

Penelitian dan pengembangan ini menghasilkan produk bahan ajar berupa Lembar Kerja Peserta Didik (LKPD) berbasis Teori van Hiele pada Materi Bangun Ruang Sisi Datar untuk Mendukung Peningkatan Kemampuan Visual Spasial Siswa SMP. LKPD ini dikembangkan dengan menggunakan metode pengembangan ADDIE, dengan tahapan analisis, tahap desain, tahap pengembangan, tahap implementasi dan tahap evaluasi. Namun, penelitian ini hanya terbatas sampai tahap implementasi karena peneliti tidak melaksanakan tahap evaluasi. Hasil validasi dari validator menunjukkan bahwa LKPD berbasis teori van hiele materi bangun ruang sisi datar untuk mendukung peningkatan kemampuan visual spasial ini valid digunakan, dengan didapat hasil rata-rata skor 4 dengan kategori valid. Berdasarkan hasil analisis angket validasi di atas disimpulkan bahwa LKPD berbasis teori van hiele untuk mendukung peningkatan kemampuan visual spasial sesuai dengan indikator. Setelah disebarkan angket dan LKPD ke peserta didik untuk dinilai kelayakan LKPD berbasis teori van hiele untuk mendukung peningkatan kemampuan visual spasial. Setelah dilakukan analisis kelayakan terhadap angket yang diisi peserta didik, diperoleh skor rata-rata 3,6 dengan kategori sangat layak. Sehingga, LKPD berbasis teori van hiele materi bangun ruang sisi datar untuk mendukung peningkatan kemampuan visual spasial SMP memenuhi aspek kevalidan dan kelayakan bahan ajar serta respon baik dari siswa, sehingga dapat dikategorikan valid dan layak.

\section{DAFTAR PUSTAKA}

Aldoobie, N. (2015). ADDIE model. American International Journal of Contemporary Research, 5(6), 68-72.

Ayllón, M. F., Gómez, I. A., \& Ballesta-Claver, J. (2016). Mathematical thinking and creativity through mathematical problem posing and solving. Journal of Educational Psychology-Propósitos y Representaciones, 4(1), 195-218. http://dx.doi.org/10.20511/pyr2016.v4n1.89

Choirudin, C., Anwar, M. S., Azizah, I. N., Wawan, W., \& Wahyudi, A. (2021). Pengembangan LKPD Matematika Berbasis Kaligrafi dengan Pendekatan Guided Discovery Learning. Jurnal Pendidikan Matematika (JPM), 7(1), 5261.Diezmann, C. M., \& Watters, J. J. (2000). Identifying and supporting spatial intelligence in young children. Contemporary Issues in Early Childhood, 1(3), 299-313. https://doi.org/10.2304/ciec.2000.1.3.6 
Hermawan, A. E., Lukman, H. S., \& Mulyanti, Y. (2019). Pengembangan lembar kerja siswa (lks) berbasis komik strip dengan metode guided discovery learning untuk materi perbandingan trigonometri. Symmetry: Pasundan Journal of Research in Mathematics Learning and Education, 4(1), 61-71. http://dx.doi.org/10.23969/symmetry.v4i1.1700

Mahnun, N. (2012). Media pembelajaran (kajian terhadap langkah-langkah pemilihan media dan implementasinya dalam pembelajaran). an-Nida' 37(1): 27-35. http://dx.doi.org/10.24014/an-nida.v37i1.310

Mohler, J. L. (2008). A review of spatial ability research. The Engineering Design Graphics Journal, $72(2)$. http://gpejournal.org/index.php/EDGJ/article/view/49

Pierre, La, D Sharon, A Robert, and Sharon D La Pierre. (2016). By center for adult learning research. https://doi.org/10.1016/j.jalz.2014.01.001

Prastika, I. Y. (2018). Penerapan Metode Penemuan Terbimbing Berbantuan Lembar Kerja Siswa Materi Garis dan Sudut dengan Assesment Portofolio dalam Meningkatkan Kemampuan Pemahaman Konsep Siswa Kelas V II. Kontinu: Jurnal Penelitian Didaktik Matematika, 1(2).

Prastowo, A. (2015). Panduan kreatif membuat bahan ajar inovatif. Yogyakarta: DIVA Press.

Pujawan, I. G. N., Suryawan, I. P. P, \& Prabawati, D. A. A. (2020). The effect of van hiele learning model on students' spatial abilities. International Journal of Instruction. 13(3), 461-474. https://doi.org/10.29333/iji.2020.13332a

Rizkiana MS, Shafara, Pupuh, D., \& Novi, P. (2019). Kemampuan visual spasial siswa dalam menyelesaikan soal bangun ruang kubus dan balok. Prosiding $\begin{array}{llllr}\text { Seminar Nasional MIPA UNIBA } 2019 . & 99-106 .\end{array}$ https://ejournal.unibabwi.ac.id/index.php/knmipa/article/view/788

Sari, C. K., Machromah, I. U., \& Zakkiyah. (2019). Developing circle module based on van hiele theory. Proceeding of the SEMANTIK Conference of Mathematics Education. 467(Semantik 2019), 72-77. https://doi.org/10.2991/assehr.k.200827.120

Sutama, (2019). Metode penelitian pendidikan (kuantitatif, kualitatif, ptk, mix method, r\&d). Sukoharjo. CV Jasmine.

Sutama. (2015). Metode penelitian pendidikan kuantitatif, kualitatif, ptk \& r\&d. Sukoharjo. Fairuz Media.

Timmins, A. C. B. (1996). Multiple intelligences: gardner's theory. Practical Assessment, Research, and Evaluation 5(1996): 10. https://doi.org/10.7275/7251-ea02

Usiskin, Z. (1982). Van hiele levels and achievement in secondary school geometry. CDASSG Project. https://eric.ed.gov/?id=ed220288 
Waluyo, E., Sa'dijah, C., \& Subanji, S. (2016). Pengembangan RPP dan LKPD Berbasis Realistic Mathematics Education dengan Memerhatikan Beban Kognitif Siswa Materi Bangun Ruang Sederhana Kelas IV SD. Jurnal Pendidikan: Teori, Penelitian, Dan Pengembangan, 1(12), 2300-2306.

Wenas, J. R., \& Sambuaga, O. T. (2017). Hubungan kecerdasan visual-spasial dengan hasil belajar matematika siswa pada materi geometri. JSME (Jurnal Sains, Matematika \& Edukasi), 5(1), 87-91. http://ejournal.unima.ac.id/index.php/jsme/article/view/170 